\title{
THE INFLUENCE OF EXPERIENTIAL MARKETING, EMOTIONAL BRANDING, BRAND TRUST TOWARDS BRAND LOYALTY
}

\author{
Retno Dewanti; Tjia Fie Chu; Steven Wibisono \\ Jurusan Manajemen, Fakultas Ekonomi dan Bisnis, BINUS University \\ Jln. K.H. Syahdan No. 9, Palmerah, Jakarta Barat 11480 \\ rdewanti@binus.edu, fie chu@binus.edu
}

\begin{abstract}
The restaurant business in jakarta showed rapidly increased. Marketing today as the compete of brand strategy and experiental marketing on the competitive situation. The Jun Jan Kitchen is a new restaurant specialized on Chinnese Food, urgent to know the brand loyalty. The Aim research is to measured the influence of Experiental marketing, emotional branding and brand trust towards brand loyalty. Research method used descriptif, data collecting technique with questioner and observation. Statistic tools using path analysis to looking for contribution level on each variabel towards other. Population this research is customer Jun Jan Kitchen. Sampling technique using accidental sampling. Amount of sample is 100 customers. Result of this research is experiental marketing giving the significant influence towards brand trust whereas Emotional branding giving the significant influence towards brand loyalty.
\end{abstract}

Keywords: Experiental Marketing, Emotional Branding, Brand Trust, Brand Loyalty.

\begin{abstract}
ABSTRAK
Bisnis restoran di jakarta menunjukkan peningkatan pesat. Pemasaran sekarang ini berperan sebagai pesaing merek dan strategi pemasaran yang berpengalaman pada situasi yang kompetitif. The Jun Jan Kitchen adalah restoran baru khusus makanan Cina, mendesak untuk mengetahui loyalitas merek. Penelitian bertujuan untuk mengukur pengaruh pemasaran Experiental, emosional dan kepercayaan merek menuju loyalitas merek. Metode penelitian yang digunakan adalah deskriptif, teknik mengumpulkan data dengan kuesioner dan pengamatan. Alat statistik menggunakan analisis jalur untuk mencari tingkat kontribusi pada setiap variabel. Populasi penelitian adalah pelanggan Jun Jan Kitchen. Teknik sampling menggunakan sampel yang disengaja. Jumlah sampel 100 pelanggan. Hasil dari penelitian ini adalah pemasaran experiental memberikan pengaruh signifikan terhadap merek kepercayaan sedangkan emosional merek memberikan pengaruh signifikan menuju loyalitas merek.
\end{abstract}

Kata kunci: pemasaran eksperimental, emotional branding, kepercayaan merek, loyalitas merek 


\section{INTRODUCTION}

Currently the growth of restaurants industry has indicate high increase which can be see through the quantity, quality, and the heterogeneous of restaurant type. This situation can be said has positive value to the industry. The expansion of the economics side, constitute positive mark that the prosperity of the food and beverage consumer society become better than before, it can be shown by the number of consumers that nowadays come into the several restaurants to have their meals or just having a good time with friends and family, also it is a sign that the appetite of consumers food and beverage become higher than before.

Together with the expansion of time and culture, formerly the main function of the restaurant is just place for offering meals for customers, and now, that function has been moved to aim that support someone lifestyle. The competition of one restaurant and others become more tight, it is because there are so many new restaurants with many kind of variations food and beverage that being offering to the market. That situation could raise the temptation of consumers likes. Also, Jun Njan Kitchen as a restaurant that already exist for many years in the restaurant field can not escaped from the competition. Jun Njan Kitchen has several compettitor in it field, like example Sapo Oriental, Red Bean who become one of the main competitor for Jun Njan Kitchen. That information be obtained from the direct observation with the owner of Jun Njan Kitchen about their competitor.

Jun Njan Kitchen which is build 2 years ago, must be can not avoid the competition of the same kind of restaurant. Period 2 years having a business in the restaurant can be said it is still fresh, because of that reason, the research about the factors of Experiential Marketing, Emotional Branding, And Brand Trust Towards Brand Loyalty Jun Njan Kitchen is important to be thorough. Only restaurant that has a high brand loyalty from consumers which is can survive in the food and beverage industry.

\section{Problem Identification}

In this step, constitute activity for looking problems that in case could become an answers through this research. These are some problems that writer want to investigate in this research, which are: (1) how the contribution of Experiential Marketing, Emotional Branding, and Brand Trust towards Brand loyalty in a simultaneous and partial; and (2) how the contribution of Experiential Marketing about Brand Trust and the impact to Brand Loyalty?

\section{Research Objectives}

Depending on the problem identification, so the objective of doing this research are: (1) to find out the contribution of Experiential Marketing, Emotional Branding, and Brand Trust towards Brand loyalty in a simultaneous and partial; and (2) to find out the contribution of Experiential Marketing about Brand Trust and the impact to Brand Loyalty.

\section{Literature Review}

\section{Experiential Marketing}

Schmitt (1999) Experiential Marketing constitute a process offering product and service by marketer to consumer with act of exciting the emotion of consumer which is result many experiences for consumer. (Usahawan, 2007, p23).

According to Tatum (2008) Experiential Marketing is a concept which combine the emotion element, logic, and all think process then connected to the consumer. The objective of Experiential 
Marketing is to build correlation where consumer respond to the product that being offered based on their emotion and think level.. Strategic concept from Experiential Marketing (Usahawan, 2007, p23) are: (1) sense marketing, it is show to the taste with creating an experience through the five senses like sight, sound, touch, taste, and smell; (2) feel marketing, directed to consumer feel and emotion with objective to contribute experience through heart feeling until the emotion of happiness and being proud; (3) think marketing, directed to intelectual with objective to create a cognitive; (4) act marketing, directed to contribute a physical experience, lifestyle, and interaction; and (5) relate marketing, include the four aspect ( Sense, feel, thnk, and act).

\section{Emotional Branding}

According to Gobe \& Travis (2001), emotional branding is a tool to create personal communication with consumer. Gobe in his book with title Emotional Branding (2001) give a concept of process emotional branding with based on four important aspects with give a strategic structure. The aspects are: (1) relationship, about the very deep relationship with consumer and show the appreciation to the consumer also give them an emotional experience that they are hope to; (2) sensorial experiences, prepare consumer with sensorial experiences from one brand constitute a main key to get a brand that easy to remember and creating brand loyalty; (3) imagination, imagination to product design, packaging, advertising, and internet site make a brand can possibly reach consumer heart; and (4) vision, become a main factor from the successful of a brand in the long time period. A brand develop through the life cycle in the market and to create and keep the marketshare, a brand must being balance with the market condition in a consistent.

\section{Brand Trust}

According to Ballester (2003), brand trust is a safety feeling that own by consumer consequence from the interaction with a brand, with based on the perception that brand can be rely on and responsible upon the safety of consumer and consumer need.

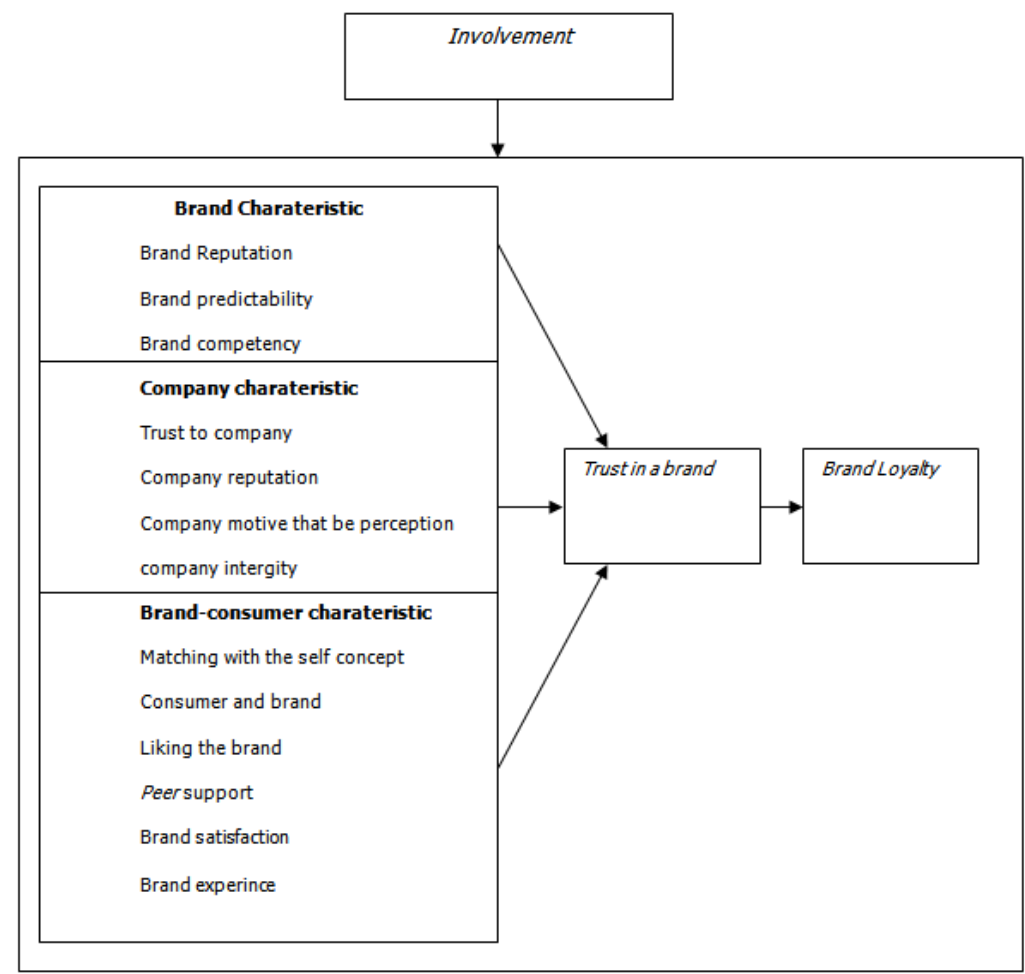

Figure 1 Consumer trust in a Brand Source: Lau \& Lee (1999) 


\section{Brand Loyalty}

According to Durianto, et al (2004), brand loyalty is a scale about the relation of consumer with a brand. This scale describe about the possibility a consumer move into another brand product, exspecially if in that brand is known any changes, like price and the other atributes. Meanwhile, according to Rangkuti (2004), brand loyalty is a scale from the consumer loyalty to the brand. According to Keegan, et al (1995), brand loyalty is a customer's tendency to have a consistenly positive attitude toward a particular brand and to purchase it repeatedly over time.

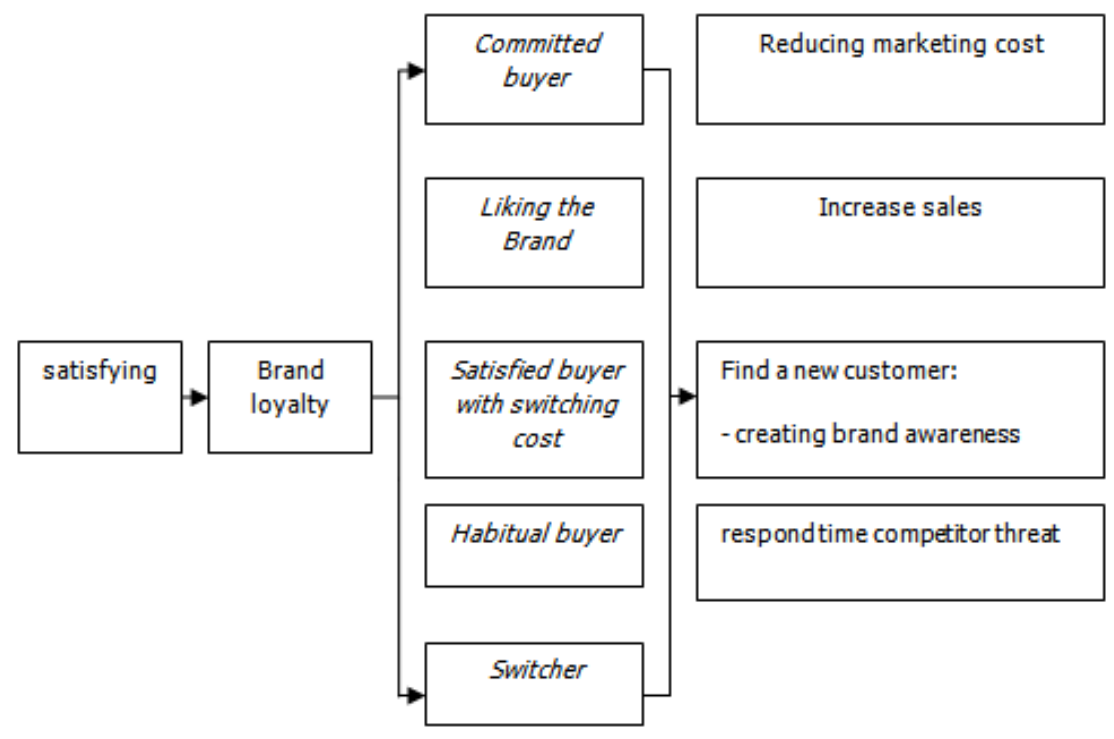

Figure 2 The Effect of Brand Loyalty

Source: Simamora (2001)

\section{METHOD}

\section{Sampling Technique}

In this research, the researcher using the simple random sampling technique, with determining number of sample technique using a slovin formula that determine the number of respondent of Jun Njan Kitchen.

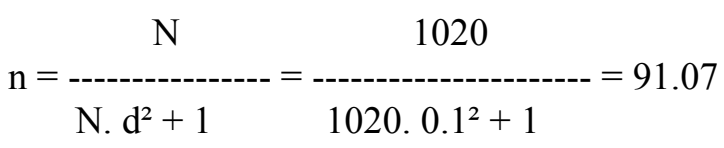

(Riduwan and Engkos, 2007: p49)

With the result above 91.07, determine number become 100 respondent. Causal correlation model X1, X2, X3 towards Y: 


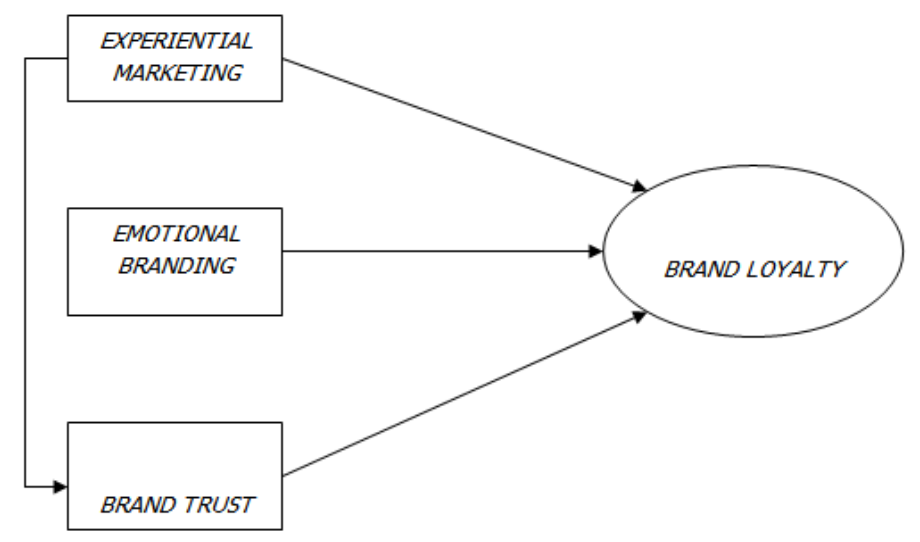

Figure 3 The causal correlation model between variables

Hypothesis test

Ho $=$ there is o no contribution between experiential marketing, emotional branding, and brand trust towards brand loyalty in simultaneous and partial.

$\mathrm{Ha}=$ there is any contribution between experiential marketing, emotional branding, and brand trust towards brand loyalty in simultaneous and partial.

Ho $=$ There is no contribution between experiential marketing towards brand trust and the impact to brand loyalty.

$\mathrm{Ha}=$ There is any contribution between experiential marketing towards brand trust and the impact to brand loyalty.

\section{DISCUSSION}

Contribution analysis of Experiential Marketing, Emotional Branding, and Brand Trust towards Brand Loyalty in simultaneous and partial. Anova analysis directed to know the contribution in simultaneous between Experiential Marketing, Emotional Branding, and Brand Trust towards Brand Loyalty Jun Njan Kitchen. The result of calculation by using SPSS program show by the Table 1.

Table 1 Anova

ANOVA

\begin{tabular}{|ll|r|r|r|r|r|}
\hline Model & & \multicolumn{1}{|c|}{$\begin{array}{c}\text { Sum of } \\
\text { Squares }\end{array}$} & df & Mean Square & \multicolumn{1}{c|}{ F } & Sig. \\
\hline 1 & Regression & 14.306 & 3 & 4.769 & 16.530 & $.000^{\circ}$ \\
& Residual & 27.695 & 96 & .288 & & \\
& Total & 42.001 & 99 & & & \\
\hline
\end{tabular}

a. Predictors: (Constant), X3, X2, X1

b. Dependent Variable: $Y$

In analyze the contribution of Experiential Marketing, Emotional Branding, and Brand Trust towards Brand Loyalty by using path Analysis method, the result is:

Ho $=$ There is no significant contribution between experiential marketing, emotional branding, and brand trust towards brand loyalty in simultaneous.

$\mathrm{Ha}=$ there is significant contribution between experiential marketing, emotional branding, and brand trust towards brand loyalty in simultaneous. 
If seen from the probability value (sig) then it obtain sig value for 0.000 , because sig value $<$ 0.05 so the decision is Ho rejected and $\mathrm{Ha}$ accepted. It means that there is significant contribution between Experiential Marketing, Emotional Branding, and Brand Trust towards Brand Loyalty. Coefficients analysis directed to know the contribution in partial or individual between Experiential Marketing, Emotional Branding, and Brand Trust towards Brand Loyalty. The result calculation with using SPSS programme show in the Table 2.

Table 2 Coefficients

Coefficients

\begin{tabular}{|c|c|c|c|c|c|c|}
\hline \multirow{2}{*}{\multicolumn{2}{|c|}{ Model }} & \multicolumn{2}{|c|}{$\begin{array}{c}\text { Unstandardized } \\
\text { Coefficients }\end{array}$} & \multirow{2}{*}{$\begin{array}{c}\begin{array}{c}\text { Standardi } \\
\text { zed } \\
\text { Coefficien } \\
\text { ts }\end{array} \\
\text { Beta } \\
\end{array}$} & \multirow[b]{2}{*}{$\mathrm{t}$} & \multirow[b]{2}{*}{ Sig. } \\
\hline & & B & Std. Error & & & \\
\hline & (Constant) & .817 & .333 & & 2.457 & .016 \\
\hline & $\times 1$ & $.154 \mathrm{E}-02$ & .781 & .061 & .079 & .937 \\
\hline & $\times 2$ & .384 & .088 & .424 & 4.364 & .000 \\
\hline & X3 & .178 & .774 & .177 & .230 & .819 \\
\hline
\end{tabular}

a. Dependent Variable: $Y$

Hypothesis 1 :

Ho $=$ There is no contribution between Experiential Marketing towards Brand Loyalty.

$\mathrm{Ha}=$ There is contribution between Experiential Marketing towards Brand Loyalty.

If seen from the probability value (sig) then it obtain sig value for 0.937 , because sig value $>$ 0.05 so the decision is Ho accepted and Ha rejected. It means that there is no significant contribution between Experiential Marketing towards Brand Loyalty. Emotional Branding have a significant contribution towards Brand Loyalty. Test in partial show by Table 1.2. The hyphotesis that will be test is:

Hypothesis 2 :

Ho $=$ There is no contribution between Emotional Branding towards Brand Loyalty.

$\mathrm{Ha}=$ There is contribution between Emotional Branding towards Brand Loyalty.

If seen from the probability value (sig) then it obtain sig value for 0.000 , because sig value $<$ 0.05 so the decision is Ho rejected and Ha accepted. It means that there is significant contribution between Emotional Branding towards Brand Loyalty. Brand Trust does not have significant contribution towards Brand Loyalty.

Hypothesis 3 :

Ho $=$ There is no contribution between Brand Trust towards Brand Loyalty.

$\mathrm{Ha}=$ There is contribution between Brand Trust towards Brand Loyalty.

If seen from the probability value (sig) then it obtain sig value for 0.819 , because sig value $>$ 0.05 so the decision is Ho accepted and Ha rejected. It means that there is no significant contribution between Brand Trust towards Brand Loyalty. Structure causal empiris correlation between X1, X2, and $\mathrm{X} 3$ towards Y can be make through strutural similarity, as follows:

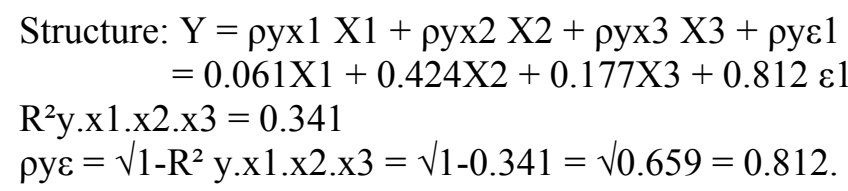




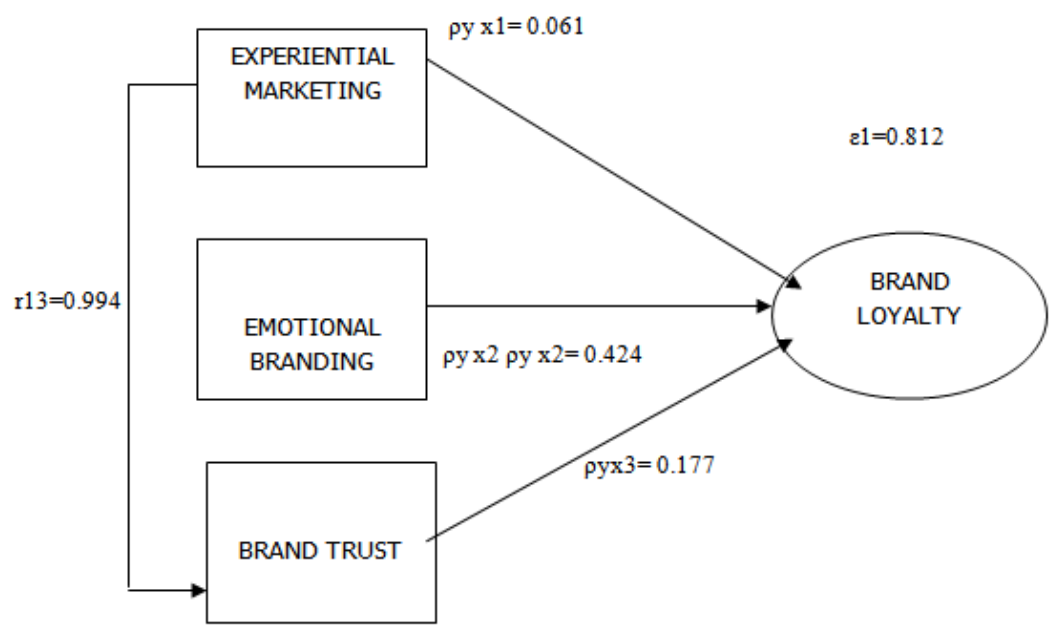

Picture 4 Path diagram causal correlation empiris Experiential Marketing (X1), Emotional Branding (X2), and Brand Trust (X3) Towards Brand Loyalty (Y)

Table 3 Path coefficient, direct contribution, total contribution and simultaneous contribution Experiential Marketing (X1), Emotional Branding (X2), and Brand Trust (X3) contribute Brand Loyalty (Y)

\begin{tabular}{|c|c|c|c|c|}
\hline \multirow{2}{*}{ Variable } & \multirow{2}{*}{ Path coefficient } & \multicolumn{2}{|c|}{ Contribution } & \multirow{2}{*}{$\begin{array}{l}\text { Simlutaneous } \\
\text { contribution }\end{array}$} \\
\hline & & Direct & Total & \\
\hline $\mathrm{X} 1$ & 0.061 & 0.061 & 0.061 & - \\
\hline $\mathrm{X} 2$ & 0.424 & 0.424 & 0.424 & - \\
\hline $\mathrm{X} 3$ & 0.177 & 0.177 & 0.177 & - \\
\hline$\varepsilon 1$ & 0.812 & $1-0.341=0.659$ & - & - \\
\hline $\mathrm{X} 1, \mathrm{X} 2$, and $\mathrm{X} 3$ & - & - & - & 0.341 \\
\hline
\end{tabular}

Based on the result of calculation structure path analysis in Tabel 4.3, so it give information in objectical as follows: (1) The value contribution of Experiential Marketing (X1) contribute Brand Loyalty (Y) is $0.061^{2}=0.00372$ or $0.372 \%$; (2) The value contribution of Emotional Branding (X2) contribute Brand Loyalty (Y) is $0.424^{2}=0.1798$ or $17.98 \%$; (3) The value contribution of Brand Trust (X3) contribute Brand Loyalty (Y) is $0.177^{2}=0.0313$ or $3.13 \%$; (4) The value contribution of Experiential Marketing (X1), Emotional Branding (X2), and Brand Trust (X3) give contribution in simultaneous contribute Brand Loyalty $(\mathrm{Y})$ is $0.341=34.1 \%$. the rest $65.9 \%$ being contribute by another factors that can not be explain in this research.

Table 4 Path coefficient, indirect contribution, total contribution Experiential Marketing (X1) towards Brand Trust (X3)

\begin{tabular}{|c|c|c|c|c|}
\hline \multirow[t]{2}{*}{ Variable } & \multirow[t]{2}{*}{ Path coefficient } & \multicolumn{2}{|c|}{ Contribution } & \multirow{2}{*}{$\begin{array}{l}\text { Simultaneous } \\
\text { contribution }\end{array}$} \\
\hline & & Indirect & Total & \\
\hline $\mathrm{X} 1$ & 0.994 & 0.994 & 0.994 & \\
\hline \multirow[t]{2}{*}{$\varepsilon 1$} & 0.110 & $1-0.988=$ & & \\
\hline & & 0.012 & & \\
\hline $\mathrm{X} 1$ & & & & 0.988 \\
\hline
\end{tabular}


Based on the result of calculation structure path analysis in Tabel 1.4, so it give information in objectical: The value contribution Experiential Marketing (X1) contribute Brand Trust (X3) is 0.9942 $=0.988$ or $98.8 \%$. The value contribution of Brand Trust (X3) towards Brand Loyalty $(\mathrm{Y})$ is $0.177^{2}=$ 0.0313 or $3.13 \%$. With the result that path analysis from X1 to Y through X3, it get $0.994 \times 0.177=$ 0.176 or $17.6 \%$.

$$
\begin{aligned}
\mathrm{X} 3 & =\rho \times 3 \times 1 \mathrm{X} 1+\rho \times 3 \varepsilon 1 \\
& =0.994 \mathrm{X} 1+0.110 \varepsilon 1 \text { dan } \mathrm{R}^{2} \mathrm{x} 3 \mathrm{x} 1=0.988
\end{aligned}
$$

Source : (Riduwan and Engkos: Analisis Jalur-Path Analysis, p145) follows.

Figure 5 is a path diagram that have been collect from the analysis result with path analysis, as

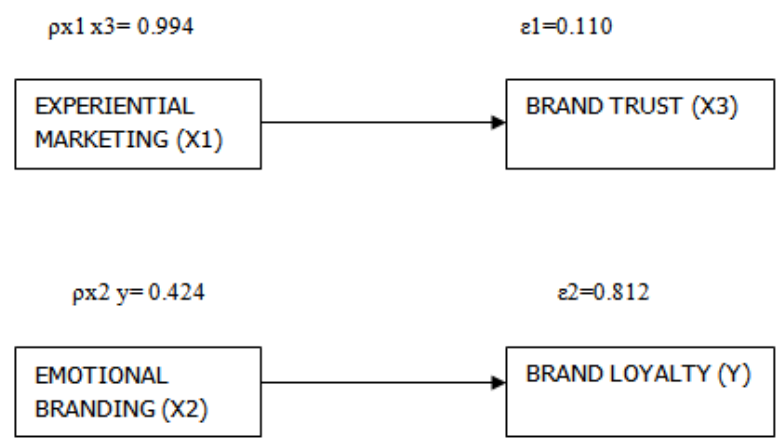

Picture 5 Path Diagram data analysis result by using path analysis

Variable Experiential Marketing and Brand Trust can not contribute variable Brand Loyalty, while variable Emotional Branding show there is contribution towards Brand Loyalty. untill variable Experiential Marketing only show very strong contribution to variable Brand Trust, and variable Brand Loyalty only being contribute by variable Emotional Branding. Ekstremly, even in theory it obtain the correlation or connection between all variable above, however in this research towards Jun Njan Kitchen does not show or give any fact or the real situation that suit with the theory.

\section{CONCLUSION}

Variable Experiential Marketing, Emotional Branding and Brand Trust show the significant contribution towards variable Brand Loyalty in simultaneous. in partial, variablel Experiential Marketing and Brand Trust does not show the significant contribution towards Brand Loyalty, while Variable Emotional Branding show the significant contribution towards Brand Loyalty. Variable Experiential Marketing in order to contribute Brand Loyalty Variable, experiential marketing need the mediation variable which is variable Brand trust where between Experiential Marketing and Brand Trust have a very strong contribution and it hope that could be give an impact to creating brand loyalty. It is suggested that Jun Njan Kitchen better not just depend on assembling Experiential Marketing and Brand Trust of Jun Njan Kitchen brand only, but Jun Njan Kitchen must look for another factors beside the emotional branding variable that can give a direct contribution to brand loyalty Jun Njan Kitchen. The most important suggestion to be concern by Jun Njan Kitchen is how to create a positive experience that can reach the level of brand trust and end with loyal to the brand of Jun Njan Kitchen by consumers. 


\section{REFERENCES}

Durianto, D., Sugiarto, \& Lie Joko. (2004). Brand equity ten. Jakarta: Gramedia Pustaka Utama.

Gobe, M. (2001). Emotional branding. New York: Allworth Press.

Jurnal USAHAWAN No. 06 Th XXXVI JUNI 2007: p23.

Rangkuti, F. (2004). The Power of Brands: teknik mengelolah brand equity dan strategi pengembangan merek. Jakarta: Gramedia Pustaka Utama. 